\title{
Pia Hovi-Assad
}

\section{PORIN KARJARANNAN}

\section{ASUNTOMESSUALUEEN TAIDEKILPAILU}

\section{Tavoitteena julkisten alveiden suunnittelijoiden ja taiteilijoiden välinen yhteistyö}

\section{The Pori Karjaranta Housing Fair's Art Competition. Aiming for co-operation between planners of public spaces and artists}

The first housing fair in Finland was organized in 1970. Since then, a housing fair has been realized almost every year in different parts of the country. In 2018, a housing fair was organised in the Karjaranta neighbourhood in Pori. In the early stages of the planning, the officials' wanted to include visual artists in the process. The aim was that artists would together with city planners develop the area to a good living environment. To reach this target, the city decided to organize an art competition for artists in the Satakunta region.

In this article I focus on public art and the planning process of the Karjaranta area. I examine, if co-design happened due to the Karjaranta art competition, and if it happened, in which stage was art included in the planning process. With a questionnaire, I research how citizens relate to a specialist run art competition. What type of public art do the inhabitants wish to have in their living environment? I reference the theories of public art by Tarja Kekäläinen, Laura Uimonen, Malcolm Miles, Cher Kraus Knight and Sharon Zukin. As research material I have written sources and image material of the Karjaranta art competition and interviews.

The conclusion of the research reveals that the Karjaranta art competition represents a model by which planning of public art and public art competitions usually proceed in Finland. The co-design was realised between the competition's working group and the participating artists. The results of the questionnaire reveal that a high percentage of those who responded support the citizens right to express their opinion on public art competitions. The respondents prefer public art, which relate to the history of the site and/or residential area. At its very best, public art creates a unique story and identity to the area.

Keywords: public art, public art competition, co-design, housing fair, city planning

\section{Johdanto}

Vuonna 1970 Suomessa järjestettyjen ensimmäisten asuntomessujen jälkeen asuntomessut on järjestetty miltei joka vuosi eri puolella maata. Alkuaikoina messujen tavoitteena oli edistää "suuren yleisön asuntotietoutta ja parantaa asuntosuunnittelun ja -rakentamisen laatua” (Kuoppamäki \& Salmi, 2001, s. 10). Tänä päivänä Suomen Asuntomessut haluaa toimin- nallaan luoda "asuinympäristöjä, joissa ihmiset voivat hyvin" (Suomen Asuntomessut/Toiminta-ajatus, s.d.). Porin Karjarannan alueella järjestettiin asuntomessut kesällä 2018. Karjarannan aluesuunnitteluun toivottiin varhaisessa vaiheessa mukaan kuvataiteilijoita, jotka yhteistyössä julkisten alueiden suunnittelijoiden kanssa loisivat asuinalueesta taiteen avulla paremman ympäristön elää (Porin kaupunki, 
Karjarannan taidesuunnittelun ideakilpailun kilpailuohjelma, 2015). Jotta yhteissuunnittelu toteutuisi, Porin kaupunki päätti järjestää satakuntalaisille kuvataiteilijoille suunnatun taidekilpailun.

Tarkastelen artikkelissani asemakaavasuunnittelun ja taidekilpailun prosessikuvauksen avulla, syntyikö Karjarannan taidekilpailun aikana moniammatillista yhteistyötä. Jos sitä syntyi, minkälaista se oli? Missä vaiheessa suunnitteluprosessia julkinen taide otettiin osaksi aluesuunnittelua? Lisäksi selvitän Karjarannan taidekilpailun finalistien näyttelyn yhteydessä olleen kyselylomaketutkimuksen avulla, mitä mieltä kaupunkilaiset olivat asiantuntijavetoisesta taidekilpailusta. Tutkimuksessa kysytään, pitäisikö kaupunkilaisille antaa mahdollisuus osallistua julkisten taidekilpailuiden suunnitteluprosesseihin? Missä vaiheessa kaupunkilaisten olisi hyvä tulla mukaan suunnitteluprosessiin ja millä tavoin he voisivat osallistua suunnitteluun? Vastaajilta kysytään myös, mikä on heidän mielestään hyvää julkista taidetta.

Tutkimukseni sijoittuu maisemantutkimuksen kentässä vaikuttavaan maisema- ja yhdyskuntasuunnittelun tutkimukseen. Näkökulmana toimivat julkinen taide ja asuinalueiden suunnittelun osallistavat metodit, kuten yhteissuunnittelu. Tutkimuksessa viitataan muun muassa kaupunki- ja yhdyskuntasuunnittelun ja julkisen taiteen tutkimuksiin, joissa selvitetään julkisen taiteen ja asukasosallistumisen muuttunutta roolia uusien asuinalueiden ja kaupunkitilojen suunnittelussa. Tutkimusaineistona on Porin Karjarannan asuntomessualueen taidekilpailun kirjallinen ja kuvallinen materiaali, asiantuntijahaastatteluita ja kyselylomaketutkimus. Kyselylomaketutkimus noudattaa poikittaistutkimuksen aineistonkeruun periaatteita, jossa aineisto on kerätty yhdessä ajankohdassa useilta vastaajilta (Vastamäki, 2015, s. 121).

Suomen Asuntomessujen toimintaan kuuluu asumisen tutkimustoiminnan edistäminen. Organisaatio on julkaissut juhlajulkaisuja, joissa kerrotaan kuvien ja esseiden välityksellä messujen historiasta. Toimintakertomukset sisältävät lyhyitä kuvauksia taidekilpailuista ja yhteistyöstä taiteilijajärjestöjen kanssa. Messujen aikana tai niiden jälkeen on toteutettu kävijäkyselyitä. Vuonna 2017 Suomen Asuntomessut on kerännyt asukasbarometrin avulla tutkimusmateriaalia suomalaisten asumisesta ja hyvinvoinnista. Kirsti Toivonen (2013) on tehnyt Lahden ammattikorkeakoulussa Ympäristöteknologian koulutusohjelman opinnäytetyön Tampereen Vuoreksen messualueen taiteesta. Asuntomessujen yhteydessä tapahtuvaa taiteilijoiden ja suunnittelijoiden välistä yhteistyötä ja taidekilpailuita ei ole tutkittu suomalaisten tutkijoiden taholta. Laura Uimonen (2010) on tehnyt Aalto yliopiston Taideteollisen korkeakouluun väitöskirjan taidehankkeista ja taidetoiveista suomalaisessa kaupunkisuunnittelussa. Vuonna 2016 Jaakko Hyry / TNS Gallup Oy on tutkinut Suomen Taiteilijaseura ry:n toimesta suomalaisten suhtautumista julkiseen taiteeseen. Kyselytutkimuksessa tarkasteltiin kansalaisten käsityksiä taiteesta osana asuinympäristöä ja julkisia tiloja (ks. Hyry, 2016). Tutkimuksessa ei käsitellä minkälaista taidetta kansalaiset toivovat julkisiin tiloihin.

Artikkelin alussa selvitetään julkisen taiteen, prosenttiperiaatteen, yhteissuunnittelun ja osallistaminen käsitteet. Tämän jälkeen käsitellään Porin Karjarannan asuntomessualueen asemakaavan ja taidekilpailun vaiheet. Seuraavassa osiossa perehdytään kyselylomaketutkimukseen ja sen tuloksiin. Taidekilpailun yleisöäänestyksen tulos ja voittajateos esitellään artikkelin lopussa. Johtopäätöksiä-osiossa on ehdotuksia siihen, miten taiteilijoiden ja asukkaiden roolia asuinalueiden ja julkisen taiteen suunnitteluprosesseissa voitaisiin edistää.

\section{Julkisen taiteen laajentunut käsite}

Julkinen taide on julkisessa tilassa sijaitsevaa taidetta, jonka rahoittajana toimii julkinen ja / tai yksityinen taho (Järvipetäjä \& Nikkilä, 2012, s. 9). Perinteisesti julkinen taideteos on ollut juhlava monumentti, näköispatsas tai muistomerkki. Tänä päivänä käsitys julkisesta taiteesta on merkittävästi laajentunut ja arkipäiväistynyt. Julkiseen taiteeseen voi törmätä kaupunkitilassa valotaululla, sen päällä voi puistossa istua tai se 
on valmistettu perinteisestä kuvanveistomateriaalista pronssista, mutta se esittää epäsovinnaista aihetta, kuten jalkakäytävälle sijoitettua koirankakkaa. 1990-luvulla kansainvälisellä taiteen kentällä keskusteltiin vilkkaasti käsitteistä kuten uusi julkinen taide, yleisöt, yhteisöt, paikka ja osallistaminen. Osallistamisella pyritään saamaan kansalaisia osallistumaan johonkin toimintaan tai päätöksentekoon. Osallistamista voi tapahtua instituutioiden toimesta, ylhäältä alaspäin tapahtuvana toimintana tai se voi myös toteutua vertaisten kesken. Parhaimmillaan se on vuorovaikutteinen prosessi, jossa osallistajan ja osallistettavan roolit vaihtuvat. (Hautio, 2016, 31.)

Taideteoksen toteutus prosessimaisen työskentelyn kautta on tuonut mukanaan uudenlaisen suhtautumisen julkiseen taiteeseen. Julkinen taideteos voi syntyä osallistamisen tai yhteisötaiteeseen sisältyvän prosessimaisen työskentelyn välityksellä. Teoksen voi suunnitella työryhmä ja sen toteutus voi tapahtua yhteisöllisen prosessin kautta, työstäen esimerkiksi asukkailta tulevia teemoja. Nykyään hyvänä julkisena taiteena pidetään teosta, joka on esimerkiksi toiminnallinen, interaktiivinen tai siihen voi koskea (Kekäläinen, 2010a, s. 51). Julkisen taideteoksen toteutuksessa paikkasidonnaisuutta tai alueen historian huomioimista suunnittelussa pidetään myös kriteereinä hyvälle julkiselle taiteelle. Katutaiteen nousun myötä julkisesta taiteesta on käyty paljon keskustelua Suomessa. 2010-luvulla katutaide ja graffiti nousivat marginaalista taidemuseoihin. Katutaiteen genreen kuuluva seinämaalaus eli niin kutsuttu muraali on hyväksytty osaksi virallista julkisen taiteen määritelmää. Nyt seinämaalauksia löytyy muun muassa talojen päädyistä eri puolilta Suomea.

Yhteiskunnan digitalisoituminen tuo mukanaan uusia tekniikoita julkiseen taiteeseen. Nykytaiteen kentällä vahvasti vaikuttava mediataide on pitkään taistellut näkyvyydestä julkisessa kaupunkitilassa mainosten kanssa. Turun kaupunginteatteri otti marraskuussa 2017 käyttöön 77 neliön suuruisen led-valotaulun, joka sijaitsee kaupunginteatterin päätyseinällä, Aleksis Kiven aukiolla. Valotaulun avulla tiedotetaan teatterin toiminnasta esityksistä otettujen valokuvien välityksellä sekä esitetään kaupungin taidemuseon mediataidehankintoja. (Haapanen, 2017.) Taiteen edistämiskeskuksen läänintaiteilija Hannele Romppasen mukaan "taideseinä luo uudenlaista näkyvyyttä nykytaiteen keskiössä olevalle mediataiteelle ja toimii samalla julkisen taiteen kehittäjänä. Digitaalisuuden kautta julkista taidetta voi ajatella myös tapahtumallisuuden ja hetkellisyyden näkökulmasta pysyvien monumenttien rinnalla." Romppanen on luonut digitaaliselle taideseinälle uuden julkisen taiteen genren "pikselimuraali". (em.)

\section{Prosenttiperiaate ja sen edistäminen}

Prosenttiperiaate tarkoittaa sitä, että julkista rakennusta tai aluetta suunniteltaessa rakennuskustannuksista noin yksi prosentti varataan taiteen hankkimiseen. Periaatetta voivat soveltaa valtion ja kunnan lisäksi yritykset, järjestöt ja yhteisöt. Sitä voi hyödyntää sekä uudis- että korjausrakentamisessa ja taidetta voidaan sijoittaa yhteisiin sisä- ja ulkotiloihin. Teoksia voi joko ostaa tai hankkia tilaustyönä suoraan taiteilijalta. (Suomen Taiteilijaseura, 2014.) Prosenttitaiteen avulla rahoitettu teos voi olla pysyvä tai väliaikainen. Esimerkiksi vuonna 2017 Jyväskylän kaupunki teki linjauksen, jonka myötä prosessiperiaatetta voidaan Kankaan asuinalueella käyttää myös tapahtuman toteutukseen (Lättilä, 2017). Jos prosenttiperiaatteella hankitut teokset sijaitsevat julkisella paikalla, ovat ne osa julkisen taiteen kenttää ja kuuluvat kunnallisen taidemuseon julkisen taiteen kokoelmaan (Kekäläinen, 2010b, s. 43). Yksityisillä rakennuttajilla on kasvava rooli julkisen taiteen rahoituksessa. Esimerkiksi Kankaan asuinalueella julkisen taiteen budjetti koostuu tonttien myyntihinnoista, maankäyttömaksuista ja kiinteistöjen rakennuskustannuksista. Rahoituksesta noin 88 prosenttia tulee yksityisiltä rahoittajilta ja 12 prosenttia kaupungilta. (Lättilä, 2017.)

Julkisten alueiden asemakaavan liitteeksi voi laatia joko ohjeellisen tai velvoittavan taideohjelman tai taidekaavan: 
"Taideohjelma on suunnitelma siitä, miten suunnittelualueelle tai kohteeseen toteutetaan taidetta ja miten taidehankinnat rahoitetaan. [...] Taideohjelma kertoo myös, kuinka tilaajien, rakennuttajien, arkkitehtien, erikoisalojen suunnittelijoiden, taiteilijoiden ja käyttäjien yhteistyö toteutetaan." (Prosenttiperiaate/Taideohjelma, s.d.)

Taiteen edistämiskeskus on käynnistänyt prosenttiperiaatteen kehittämisohjelman, joka keskittyy vuosille 2014-2018. Ohjelman tavoitteena on laadukkaan ympäristön tuottaminen ja taiteilijoiden sekä muotoilijoiden työllistyminen (Turpeinen ym., 2016, s. 4, 6). Taiteen edistämiskeskuksen Satakunnan alueen Porin toimipisteen läänintaiteilijan tehtäväkuvaan kuuluu julkinen taide ja prosenttiperiaate, jonka mukaisesti taide on mukana suunnittelussa alusta alkaen. Prosenttiperiaate on kirjattu Porin kaupungin taidemuseon (Porin taidemuseon) kokoelmapoliittiseen ohjelmaan.

Kulttuuriteorian professorin Malcolm Milesin (1997, s. 13-14, 104-105) mielestä taiteilijoiden kannattaa taideobjektien tuottamiseen sijaan osallistaa asukkaita dialogiin, joka synnyttää uudenlaista julkista taidetta sosiaalisen prosessin kautta. Asuntomessualueet ovat uusia asuinalueita, joten Milesin esittämä taiteilijan ja asukkaiden välinen dialogi ei ole mahdollinen. Jotkut asuntomessujen isäntäkunnat ovat etsineet tähän ratkaisua osallistamalla kaupungin asukkaita messualueen suunnitteluun. Esimerkiksi Mikkelin vuoden 2017 asuntomessujen suunnittelun aikana, Mikkelin kaupunki järjesti palvelumuotoilutyöpajan, jossa kerättiin asukkaiden näkemyksiä messualueesta vuorovaikutteisella digitaalisella karttasovelluksella (Mikkelin kaupunki, 2017). Asuntoalueen suunnittelua varten on mahdollista toteuttaa muuttohalukkuutta koskeva kysely, jonka avulla voi saada tietoa alueen suunnitteluun ja rakentamiseen liittyvistä toiveista. Myös asukastestiryhmän voi perustaa edustamaan tulevia asukkaita. (Ympäristöministeriö, 2007, s. 31.) Tällä tavalla olisi myös mahdollista saada tietoa asukkaiden toiveista julkisen taiteen suhteen.

\section{Osuuskunta Suomen Asuntomessut ja julkinen taide sekä prosenttitaide}

Osuuskunta Suomen Asuntomessut on omaksunut julkisen taiteen osaksi toimintaansa, vaikka sitä ei ole kirjattu toimintastrategiaan. Osuuskunta ei aktiivisesti aja prosenttitaidetta messualueille, mutta se on pyrkinyt toiminnassaan noudattamaan prosenttiperiaatetta. Periaatteen noudattaminen riippuu siitä, mikä on messukunnan linja prosenttitaiteen suhteen. Messualueilla pyritään järjestämään arkkitehtuurikilpailuja ja taide halutaan osaksi asukkaiden arkea tuomalla se puistoihin ja nivomalla se esimerkiksi osaksi asuinalueella olevia lähiliikuntapalveluja. (Heiskanen, haastattelu, 7. 10. 2015.)

Messualueiden julkisessa ulkotilassa olevan taiteen laajamittainen esittely on käynnistynyt vuonna 2002 ulkoveistosnäyttelyllä (Suomen Asuntomessut, Messuhistoria, s.d.). Vähitellen messujen julkinen taide toteutettiin ympäristötaiteena osana rakennettua messuympäristöä (Loppuraportti Asuntomessut Oulussa 2005, s. 13). Messuille on vuosien saatossa tuotettu sekä pysyviä että väliaikaisia taideteoksia. Vuodesta 2010 monella asuntomessualueilla on tehty taideohjelma taitaidekaava, joka usein pohjautuu prosenttiperiaatteen soveltamiseen. (ks. esim. Prosenttiperiaate / taideohjelma -verkkosivu) Esimerkiksi Jyväskylän vuoden 2014 asuntomessuille tehtiin julkisen taiteen yleissuunnitelma, jossa pysyvät taideteokset saivat olla itsenäisiä taideteoksia tai osana ympäristön rakenteita. Kyseeseen saattoi myös tulla tapahtuman järjestäminen. (Äijälänrannan asuntomessualueen taidekonsepti, 2011, s. 6, 10.) Vuoden 2015 asuntomessuilla Vantaan Kivistössä taide liitettiin kaikkeen arkkitehtuuri- ja ympäristösuunnitteluun alusta alkaen. "Taideohjeesta" vastasi asemakaavasuunnittelija, arkkitehti AnnaRiitta Kujala. (Vantaan Asuntomessut loppuraportti, 2015, s. 8.) Julkisissa ulkotiloissa Kivistössä taidetta on muun muassa talojen julkisivuissa ja kaduilla. Asuntomessualueilla "ympäristön viimeistelytaso on näkynyt muun muassa katu- ja aukiorakentamisen ja -pinnoitteiden, leikkivälineiden, valaisimien, veistosten 
sekä muun ympäristötaiteen kehittämisenä ja toteuttamisena” (Kuoppamäki \& Salmi, 2001, s. 70.)

\section{Yhteissuunnittelu}

Asiantuntijoiden välistä yhteistyötä kutsutaan moniammatilliseksi yhteistyöksi ja moniammatilliseksi tiimityöksi, joista moniammatillinen yhteistyö on laajempaa, koska sen toteuttamiseen voi osallistua eri hallinnonalan edustajia. Mikäli asiantuntijat edustavat eri hallinnonaloja, toteutuu poikkihallinnollinen verkostotyö. Jos yhteistyössä on vielä mukana tekijöitä yksityiseltä sektorilta, puhutaan moniammatillisessa verkostotyöstä. (Isoherranen ym., 2008, s. 34-35, 37.) Kaupunkisuunnittelussa sekä kulttuurialalla käytetään edellä mainittujen käsitteiden lisäksi yhteissuunnittelua (co-design). Yhteissuunnittelua ja yhdessä luomista (co-creation) käytetään usein synonyymeinä (Sanders \& Stappers, 2008, s. 6). Kaupunkisuunnittelussa yhteissuunnittelua on hallinnon, asukkaiden ja muiden intressitahojen välinen yhteistyö (Harju, 1988, 9). Tässä artikkelissa käytetään molempia määritelmiä; suunnittelijoiden ja taiteilijoiden välisellä yhteistyöllä tarkoitetaan suunnittelua, jossa ammattisuunnittelijat ja taiteilijat, joilla ei ole suunnittelijan koulutusta, työskentelevät yhdessä suunnitteluprosessissa. Karjarannan taidekilpailun finalistien näyttelyn yhteydessä toteutetussa kyselylomaketutkimuksessa puhutaan yhteissuunnittelusta, johon osallistuisi taiteilijoiden, taiteenasiantuntijoiden, arkkitehtien, suunnittelijoiden eli asiantuntijoiden ohella asukkaat.

Karjarannan taidekilpailun tavoitteena oli kehittää Karjarannan julkisia alueita taidesuunnittelulla. Rakennushankkeiden suunnitteluun toivottiin mukaan kuvataiteilijoita, "jotka yhteistyössä julkisten alueiden suunnittelijoiden kanssa suunnittelevat aluetaideinnovaatioita paremmasta ympäristöstä” (Porin kaupunki, Karjarannan taidesuunnittelun ideakilpailun kilpailuohjelma, 2015). Kilpailuohjelmassa todetaan, että "taidesuunnittelun yhdistäminen alueen muuhun suunnitteluun mahdollisim- man varhaisessa vaiheessa luo hyvät edellytykset taiteen ja suunnittelun yhteensovittamiselle laadukkaaksi kokonaisuudeksi." (em.) Tällä konseptilla tavoiteltiin dialogia taiteilijoiden ja suunnittelijoiden välille. Dialogi koettiin kilpailussa tärkeäksi, koska sen avulla pyrittiin tukemaan taiteilijoita suunnittelutyössä. Läänintaiteilija Marjo Heino, joka oli laatimassa kilpailuohjelmaa, piti tätä tarpeellisena, koska kuvataiteilijan koulutus ei pätevöitä aluesuunnitteluun ja kuvataiteilijan ammatissa toimitaan paljon pienemmässä mittakaavassa (Heino, haastattelu, 11. 8. 2015). Ajatuksena oli, että suunnittelijat voivat välittää taiteilijoille yksityiskohtaista tietoa alueen kaavasta, jota he voisivat hyödyntää teosehdotuksen ideoinnissa.

\section{Karjarannan asuntomessualueen kaavan eteneminen ja asemakaavan osalliset}

Porin kaupunki käynnisti asuntomessujen hakuprosessin helmikuussa 2013 (Kyhä-Mantere, 2013). Osuuskunta Suomen Asuntomessujen hallitus päätti toukokuussa 2013, että Pori saa järjestettäväkseen asuntomessut vuonna 2018 (Salminen, 2013). Alueelle päätettiin rakentaa urbaani pientaloalue, johon sijoittuisi viher- ja katualueita, Kokemäenjoen rantaan nivoutuva rantabulevardi, julkista taidetta ja ruokapuisto, joka sijoitetaan messualueen vastarannalle. (Karjaranta21 / Asuntomessuteemat, s.d.) Ruokapuistoon oli tarkoitus istuttaa juurikasveja, hedelmäpuita ja marjoja (Laasanen \& Laakso, 2013). Alueen asemakaavamuutokset käynnistyivät päätöksen jälkeen. Messualueen kaavan vireilletulokuulutus annettiin marraskuussa 2013, jonka jälkeen asemakaavan muutos ja osallistumis- ja arviointisuunnitelma laitettiin nähtäville.

Osalliseksi määritelty Porin kaupungin kulttuurilautakunta antoi lausunnon, jossa se korosti, että "messualueen suunnittelun eri vaiheissa tulee huomioida julkiseen rakentamiseen kohdistuva prosenttiperiaate" (Porin kaupungin kulttuurilautakunta, KAUS /1143/2013). Lautakunnan mielestä "suunnittelussa tulisi heti 
alusta lähtien ottaa huomioon taiteen rooli alueiden viihtyvyyden, sosiaalisuuden, itsenäisen selviytymisen ja turvallisuuden tunteen lisäämisessä” (em.). Asemakaavaluonnos sekä osallistumis- ja arviointisuunnitelma, johon oli lisätty kulttuurilautakunnan lausunto, olivat nähtävillä loppuvuodesta 2014 (Porin kaupunkisuunnittelu, 2014a, s. 26). Messualueen asemakaavaehdotus oli nähtävillä kesällä 2015. Se sisälsi kulttuurilautakunnan lausunnon ja "Karjarannan taidesuunnittelu" -osion, jossa annettiin määräys taiteen liittämisestä alueen arkkitehtuuriin ja ympäristöön. Lisäksi siihen kirjattiin kaksivaiheisen kilpailun tavoitteet. (Porin kaupunkisuunnittelu, 2014b, s. 26.)

Taidemaalariliiton mukaan yksittäisen taiteilijan mahdollisuus vaikuttaa kaavoitukseen on rajallista. Liiton mielestä taiteilijoiden edustajina suunnittelussa voivat toimia paikalliset taiteilijayhdistykset, alueelliset taidetoimikunnat ja aluetaidemuseot. (Taidemaalariliitto, s.a.) Karjarannan asemakaavan muutosprosessissa kulttuurilautakunta on toiminut taiteilijoiden edustajana, ottamalla kantaa prosenttitaiteen käyttöönottoon alueen suunnittelussa. Kaavan osallistumis- ja arviointisuunnitelmassa mainitaan osallisiksi "toteuttajat". Karjarannan taidekilpailun voittanutta taiteilijaa voisi pitää toteuttajana, jolloin hän on osallinen ja hänellä on oikeus ilmaista kantansa asemakaavaan.
Tämä ei kuitenkaan käytännössä ollut mahdollista, sillä asemakaava oli hyväksytty ennen kuin kilpailun voittaja valittiin. Porin kaupunginvaltuusto hyväksyi kaavan elokuussa 2015 ja se oli lainvoimainen lokakuussa 2015. (Porin kaupunkisuunnittelu, s.d.) Kilpailun voittaja valittiin marraskuussa 2015.

Aluesuunnittelun ja julkisen taiteen toteuttaminen erillään asemakaavasuunnittelusta ylläpitää työkulttuuria, jossa kuvataiteilijoiden osaamista ei huomioida kaupunkitilojen suunnittelussa. Maankäyttö- ja rakennuslain mukaan "kaavan laatijan tulee olla pätevä tehtävään" (Maankäyttö- ja rakennuslaki, 1999 / 132, 10 §). Pätevyydestä säädetään tarkemmin asetuksella, jonka mukaan kaavan laatijalla tulee olla "suunnittelutehtävään soveltuva korkeakoulututkinto ja tehtävän vaativuuden edellyttämä riittävä kokemus" (Maankäyttö- ja rakennusasetus, 1999 / 895, 3 §). Näitä kriteereitä olisi mahdollista soveltaa rekrytoinnissa, jos suunnittelutiimin jäseneksi haluttaisiin kuvataiteilija. Suomessa ensimmäinen merkittävä asuinalue, joka toteutettiin suunnittelu- ja taiteilijayhteistyön kautta, on Helsingissä sijaitseva Arabianranta. Alueen tontinluovutuskirjoihin liitettiin prosenttitaide. Helsingin kaupunki palkkasi hankkeeseen taiteellisen koordinaattoriksi henkilön, jolla on taiteen maisterin tutkinto. Kaupunkisuunnitteluviraston tavoitteena oli asuinalueen kult-

\begin{tabular}{|l|l|l|}
\hline $\begin{array}{l}\text { Suunnittelu- ja lähialueen maano- } \\
\text { mistajat }\end{array}$ & Tulevat asukkaat & Yritykset \\
\cline { 3 - 3 } Yhteisöt & Muut & Metso Paper Oy \\
\hline $\begin{array}{l}\text { Luodon Siirtolapuutarhayhdidstys } \\
\text { ry, Melamajavat ry, Porin yrittäjät } \\
\text { ry, Karjarannan asukasyhdistys ry, } \\
\text { Huvilajuopayhdistys ry, Hevosluo- } \\
\text { don palstaviljelijät ry }\end{array}$ & $\begin{array}{l}\text { Muut asukkaat, toteuttajat, käyttä- } \\
\text { iäryhmät, Karjarannan vuorovaiku- }\end{array}$ & $\begin{array}{l}\text { Satakunnan Museo, Satakuntaliitto, } \\
\text { Varsinais-Suomen ELY-Keskus, }\end{array}$ \\
\hline $\begin{array}{l}\text { Alueen toimijat ja teknisen huollon } \\
\text { hoitajat }\end{array}$ & Asianosaiset lautakunnat & Porin tulvasuojeluhanke \\
\hline $\begin{array}{l}\text { Satakunnan Vihertietokeskus, Porin } \\
\text { Vesi, Pori Energia Sähköverkot Oy, } \\
\text { Pori Energia Oy Energiayksikkö }\end{array}$ & $\begin{array}{l}\text { Satakunnan pelastuslaitos, } \\
\text { tekninen-, ympäristö-, kasvatus- ja } \\
\text { opetus-, perusturva-, vapaa-aika-, } \\
\text { ja kulttuurilautakunta }\end{array}$ & $\begin{array}{l}\text { Porin seudun matkaily Oy MAISA, } \\
\text { konsernihallinto, Ympäristöministeriö } \\
\text { / kansallisten kaupunkipuistojen } \\
\text { valvonta, Aalto-yliopisto }\end{array}$ \\
\hline
\end{tabular}

Kuvio 1. Taulukko osallistumis- ja arviointisuunnitelman osallisista. 
Vireille:

osallistumis- ja arviointisu-

unnitelma 29. 11.2013

Suunnitelma nähtävillä:

30. 11. - 23. 12. 2013
Asemakaavaluonnos ja päivitetty

osallistumis- ja arviointisuunnitelma nähtävillä:

1. 11. - 1. 12. 2014

Asemakaavaehdotus nähtävillä:

4. 6. - 3. 7. 2015

Taidekilpailun I vaihe 15. 1. - 15.5. 2015

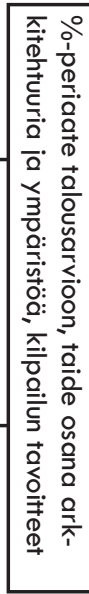

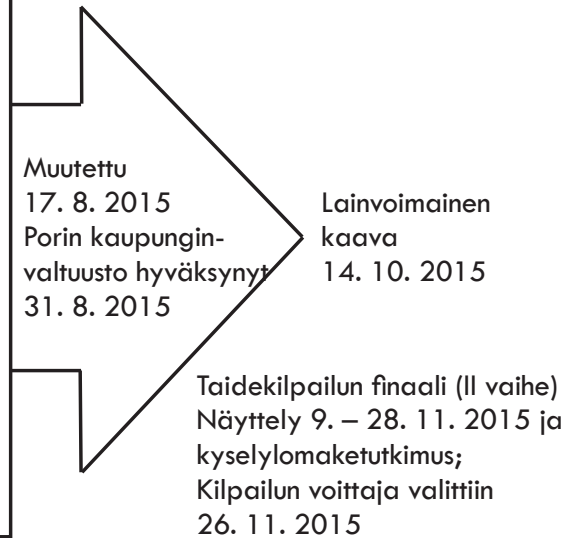

Kuvio 2. Prosessikaavio Karjarannan asuntomessualueen asemakaavan ja taidekilpailun vaiheista.

tuurikerrostumien korostaminen taiteen avulla. Taiteellisen yhteistyön toteutuminen edellytti laaja-alaista yhteistyötä kaupungin toimialojen, rakennuttajien, alueen toimijoiden, taiteilijoi den ja taidekoordinaattorin välillä. (Isohanni, 2006, s. 10, 44, 46.) Uusimpia asuinalueita, jotka ovat syntyneet suunnitteluyhteistyön tuloksena, ovat Vantaan Leinelä, Vantaan Kivistö, Jyväskylän Kangas, Porvoon Länsiranta ja Kuopion Savilahti (Kaukovirta, 2018).

\section{Taidekilpailun prosessikuvaus: tausta, työryhmän perustaminen, kilpailun konsepti ja kilpailun eri vaiheet}

Toimiessani Porin taidemuseon näyttelyamanuenssina, otin yhteyttä läänintaitelija Marjo Heinoon Taiteen edistämiskeskuksen Porin toimipisteeseen syksyllä 2014 ehdottaen yhteistyötä prosenttiperiaatteen soveltamisessa Karjarannan asuntomessuilla. Läänintaiteilija Heino kävi esittelemässä mahdollisia prosenttitaiteen kohteita Porin kaupungin kaupunkisuunnittelupäällikkö Olavi Mäkelälle ja apulaiskaupunginjohtaja Kari Hannukselle. Esitetyistä prosenttitaiteen kohteista Mäkelä ja Hannus kiinnostuivat erityisesti prosenttitaiteen soveltamisesta asuntomessuille. (Heino, haastattelu, 8. 8. 2015.) Porin kaupungin edustajiksi Karjarannan alueen taidesuunnittelu- kilpailun työryhmään valittiin kaavoitusarkkitehti Otto Arponen ja suunnitteluhortonomi Katja Pesonen. Arposen ollessa kiireinen kaavoitustyön vuoksi hänen tilallaan toimi kaupunkisuunnittelun projektipäällikkö Heli Nukki (Pesonen, haastattelu 29. 10. 2015). Työryhmän kolmas jäsen oli läänintaiteilija Marjo Heino.

Työryhmän jäsenet laativat kilpailuohjelman ja taidekonseptin, jossa taiteilijoita ja suunnittelijoita haastettiin yhteistyöhön. Porin kaupunki anoi Taiteen edistämiskeskukselta prosenttitaiteen avustusta Karjarannan taidekilpailun toteutusta varten. Kilpailun toteutukseen myönnettiin 22000 euroa, jonka myötä kaupunki julisti kaksivaiheisen avoimen ideakilpailun satakuntalaisille kuvataiteilijoille 15. 1. - 15. 5. 2015 välisenä aikana. Kilpailun hallinnollisina toimijoina olivat Porin kaupunkisuunnittelu ja Porin kaupungin Teknisen palvelukeskuksen katu- ja puistosuunnittelu. Kilpailun ensimmäinen vaihe oli ideakilpailu, jossa etsittiin ehdotuksia Karjarannan julkisille alueille, kuten viheralueille, rantabulevardille ja katualueille. Ehdotukset voivat liittyä esimerkiksi leikkipaikkoihin, rantojen muokkaamiseen, valo- ja katusuunnitteluun, tulvasuojelurakenteisiin, materiaaleihin ja väreihin (Porin kaupunki, Karjarannan taidesuunnittelun ideakilpailun kilpailuohjelma, 2015.) Karjarannan taidekilpailun ensimmäiseen vaiheeseen tuli 61 ehdotusta, joista palkintolautakunta valitsi jat- 
koon seitsemän. Kilpailun toiseen vaiheeseen osallistuivat jatkoon päässeet ehdotusten tekijät. Jatkokehittelyssä taiteilijoilla oli mahdollisuus käyttää välityshenkilöiden muodostaman työryhmän asiantuntemusta. Marraskuussa 2015 jatkokehitellyistä ehdotuksista tehtiin näyttely Porin kaupunginkirjaston näyttelytilaan. Jokaiselle näyttelyyn osallistuvalle taiteilijalle maksettiin 3000 euron palkkio.

Läänintaiteilija Heino toimi hankkeessa koordinaattorina ja asiantuntijana sekä helpottamassa suunnittelijoiden ja taiteilijoiden välistä yhteistyötä. Itse toimin tarvittaessa konsulttina, mutta minulla ei ollut aktiivista roolia kilpailun organisoinnissa. Työryhmän jäsenet hoitivat palkintolautakunnan ja kilpailijoiden välisiä yhteyksiä. Tämä oli tärkeä tehtävä, koska palkintolautakunnan jäsenten ja kilpailijoiden väliset yksityiset neuvottelut ja mielipiteiden vaihto kilpailua koskevista asioista olivat kilpailun kestäessä kiellettyjä. Välityshenkilöt eivät saaneet ottaa osaa palkintolautakunnan työhön.

Jotta taiteilijat, arkkitehdit ja suunnittelijat lähentyisivät toisiaan, järjestin läänintaiteilija Marjo Heinon kanssa taidekilpailun oheisohjelmana koulutusta ja yhteisiä tapaamisia. Ensimmäisen Art @ the Heart of the City! -seminaarin tavoitteena oli koota yhteen taiteilijoita, kaavoittajia, virkamiehiä ja taiteen kentän toimijoita. Tässä onnistuttiin hyvin, sillä seminaariin osallistui yhteensä 70 henkeä. Osallistujat pitivät seminaaria hyvänä avauksena keskusteluun, jota käydään moniammatillisesta ja poikkihallinnollisesta yhteistyöstä. Osanottajien osallistuminen yleiseen keskusteluun seminaarissa oli vilkasta. Muun muassa vertailtiin, miten kaavoittajien ja taiteilijoiden välinen yhteistyö toteutuu eri puolella Suomea.

Seuraavaksi taiteilijoille järjestettiin vierailukäynti Porin kaupunkisuunnitteluun. Tilaisuudessa esiteltiin asuntomessualue ja taiteilijoilla oli mahdollisuus tavata suunnittelutiimin jäseniä. Toisessa seminaarissa oli koulutusta kustannusarvion ja kilpailuehdotuksen tekoon. Seminaarin jälkeen taiteilijoille, arkkitehdeille ja suunnittelijoille järjestettiin "Post seminar - Kohtaa kollega!" -tapaaminen yhdessä SataSAFA:n (Satakunnan Arkkitehdit) kanssa.
Lisäksi Taiteen edistämiskeskuksen Prosentti taiteelle -hanke järjesti taiteilijoille koulutuspäivän. Karjarannan alueelle organisoitiin kevään aikana kaksi tutustumiskävelyä, joista ensimmäisellä oli mukana Porin kaupungin tulvasuojelun asiantuntija, projektipäällikkö Pekka Vuola. Ensimmäisen kävelyn yhteydessä oli mahdollisuus tutustua Karjarantaa käsittelevään valokuvanäyttelyyn, joka kertoi alueen historiasta muun muassa valokuvin. Näyttelyn olivat toteuttaneet Turun yliopiston Kulttuurituotannon ja maisemantutkimuksen koulutusohjelman opiskelija Helene Kaarnametsä ja Porin kaupungin kaavoitusarkkitehti Daniel Nagy. Läänintaiteilija järjesti jatkoon päässeille taiteilijoille koulutuspäivän.

Edellä kuvattu prosenttitaiteen käynnistymisprosessi edustaa mallia, jonka mukaan julkisen taiteen suunnitteluprosessit Suomessa usein etenevät. Arkkitehti Laura Uimosen (2010, s. 183) mukaan "aloitteen taideteoksista tai taiteen erityisestä roolista suunnittelussa voi tehdä yksittäinen taiteilija, suunnittelija tai jokin hallinnollinen elin, kuten taidemuseo, tai yhdistys tai yritys". Karjarannan tapauksessa aloitteen prosenttitaiteen soveltamisesta teki kulttuurilautakunta. Taidemuseonjohtaja edustaa kaupungin taidemuseota kulttuurilautakunnassa. Karjarannan taidekilpailun suunnitteluprosessin ytimessä oli hanketta eteenpäin vievänä organisaationa Porin kaupunki. Porin kaupungin puolesta työryhmässä on toiminut virkamiehiä kaupunki- ja puistosuunnittelusta.

\section{Kyselylomaketutkimus Karjarannan taidekilpailusta ja julkisesta taiteesta}

Toteutin kyselylomaketutkimuksen marraskuussa 2015 Karjarannan taidekilpailun finalistien näyttelyn yhteydessä. Kyselyä oli saatavilla paperiversiona ja siihen oli myös mahdollista vastata internetissä, joko paikanpäällä olleella tietokoneella tai muualla. Kyselylomaketutkimuksella tavoiteltiin tietoa siitä, mitä mieltä kaupunkilaiset ovat asiantuntijavetoisesta taidekilpailusta, millä tavoin kaupunkilaiset voisivat osallistua julkisen taiteen suun- 
nitteluun ja mikä on hyvää julkista taidetta. Kyselystä lähetettiin mediatiedote paikallislehdille ja -radioille sekä verkkoviestintää toteuttaville tahoille. Tiedote julkaistiin Satakunnan Kansan verkkolehden kulttuuri-sivulla (palveluun ei tarvitse kirjautua), ilmaisjakelulehdessä, Porin yliopistokeskuksen verkkosivulla ja viikkotiedotteessa.

Kyselyn ensimmäiset neljä kysymystä keskittyivät vastaajan taustatietoihin (sukupuoli, ikä, koulutustaso, asuinalue). Taustakysymysten jälkeen seurasi kolme kysymystä Porin tulevista asuntomessuista. Vastaajalta tiedusteltiin muun muassa, oliko hän osallistunut asuntomessualueen kaavan yleisötilaisuuksiin ja oliko vastaaja seurannut mediassa käytävää keskustelua messuista. Kyselyn kolmannen osion aiheena oli Karjarannan taidekilpailu. Ensimmäinen kysymys tiedusteli vastaajan kantaa asiantuntijavetoiseen taidekilpailuun. Vastaajalta kysyttiin, pitäisikö kaupunkilaisille antaa mahdollisuus osallistua julkisen taiteen suunnitteluprosesseihin. Jos tähän kysymykseen vastasi kyllä, pyydettiin tarkennusta siihen, missä vaiheessa kaupunkilaisten olisi hyvä saada osallistua suunnitteluprosessiin. Tämän jälkeen vastaajaa pyydettiin valitsemaan tai avoimella kysymyksellä ehdottamaan erilaisia suunnitteluosallistumisen tapoja, joita hän mieluiten suosisi.

Kyselynviimeinenosiokäsittelijulkistataidetta. Vastaajalta tiedusteltiin, mikä hänen mielestään on "hyvää julkista taidetta". Vastaajalla oli mahdollisuus valita yksi tai useampi vaihtoehto monivalintavastauksista ja hänellä oli myös mahdollisuus vastata kysymykseen vapaasti. Tähän osioon oli valittu yleisesti käytössä olevia käsitteitä, kuten "patsas", "muistomerkki", "kokonaisvaltainen suunnittelu (materiaalit, värit)", "interaktiivinen teos (vrt. Maire-veistos kävelykadulla)", "valotaideteos", "teos, johon on liitetty luonnon elementtejä kuten vettä", "seinämaalaus" ja "videoteos". Monivalintaosiossa oli lueteltu hieman epätavallisempia, mutta kuitenkin selkeitä ja helposti ymmärrettäviä määritelmiä taideteoksista, kuten "liikuteltava teos", "lyhytkestoinen teos kuten tapahtuma tai esitys" sekä "yhteisöllinen teos".

\section{Vastausten analyysi}

Kyselyn aineiston analyysi toteutettiin Webropol-sovelluksen tuottaman perusraportin pohjalta laadullisella sisällönanalyysilla, jossa pyritään tarkasteltavien teemojen kokonaisvaltaiseen käsittelyyn (Kiviniemi, 2010, s. 80). Kyselyyn tuli yhteensä 51 vastausta, joista 36 kappaletta oli sähköisiä ja 15 paperivastauksia. Vastauslomakkeet olivat huolellisesti täytetty, eikä yhtään lomaketta tarvinnut hylätä. Vastaajista $60 \%$ oli naisia. Eniten vastaajia oli 35-44 -vuotiaissa, joilla on korkeakoulutasoa vastaava koulutus.

Vastaajista suurin osa oli tietoinen siitä, että Karjarantaan on tulossa asuntomessut. Moni kertoi seuranneensa messuista käytyä keskustelua mediassa. Neljä henkilöä oli osallistunut Karjarannan asuntomessualueen asemakaavan esittelytilaisuuksiin. Ylivoimaisesti suurin osa vastaajista $(80 \%)$ oli sitä mieltä, että kaupunkilaisilla pitäisi olla mahdollisuus osallistua taidekilpailuiden suunnitteluprosesseihin. Vastaajat ovat sitä mieltä, että asiantuntijavetoista taidekilpailua pitäisi kehittää niin, että asukkailla olisi mahdollisuus asiantuntijoiden rinnalla olla mukana suunnittelussa. Pääosa vastaajista ilmoitti haluavansa olla mukana suunnittelussa jo ideointivaiheessa, mutta myös loppuvaiheessa, kun valitaan teoksia, sai paljon kannatusta. Vastaajat pitivät parhaimpana osallistumistapana julkista esittelyä ja keskustelutilaisuutta, mutta ainoastaan neljä vastaajista oli osallistunut asemakaavan esittelytilaisuuksiin.

Toiseksi parhaana tapana osallistumistapana pidettiin internet-kyselyä. Kolmanneksi tavaksi nousi työpajatyöskentely. Yksittäiset vastaajat ehdottivat muunlaisina osallistumistapoina tapaamisia kilpailuun osallistuvien taiteilijoiden kanssa, yhteisöllistä ideointia ja suunnittelua sekä ideoista toteutettavia äänestyksiä. Yksi vastaaja ehdotti mahdollisuutta osallistua taideteoksen konkreettiseen toteuttamiseen.

Kyselyn vastaajat pitivät hyvänä julkisena taiteena teosta, johon on liitetty luonnon elementtejä, kuten vettä (80\%). Toiseksi eniten kannatusta sai teoksen kokonaisvaltainen suunnittelu (75 \%). Tämän jälkeen eniten kannatus- 
ta sai interaktiivinen taideteos, jota voi käyttää esimerkiksi istuimena (67\%). Kaupunkitilaan toivottiin seinämaalauksia ja valotaideteoksia. Kannatusta saivat myös yhteisöllinen teos, patsas, lyhytkestoinen teos kuten tapahtuma tai esitys, videoteos ja liikuteltava teos.

Avovastauksissa ehdotettiin paikkasidonnaista teosta ja kokonaisvaltaista suunnittelua, joka voi sisältää kaikkia edellä lueteltuja teosmuotoja. Toivottiin myös, että taide ei olisi päälle liimattu tekijä vaan kiinteä osa suunnittelua, toteutusta ja yhteisön toimintaa. Lisäksi kaupunkitilaan ehdotettiin fyysisiä elementtejä, joita voisi koskea, käyttää ja joihin voisi jollakin tavalla jättää jälkensä. Tärkeänä pidettiin myös sitä, että teos mielekkäällä tavalla nivoutuu paikkaan ja aikaan sekä herättää katsojassa rakentavia kysymyksiä. Toivottiin myös teosta, johon tulevat asukkaat voisivat vaikuttaa tai osallistua ja jonka myötä asuinalueelle voitaisiin luoda omintakeista luonnetta.

\section{Taidekilpailun voittajateos Aurinkokaupunki}

Karjarannan taidekilpailun finalistien näyttelyn yhteydessä järjestettiin yleisöäänestys, jossa yleisö sai äänestää mieluisinta teosta joko paikan päällä näyttelytilassa tai internetin välityksellä. Mirja Vallinojan Aurinkokaupunki osoittautui yleisön suosikiksi, joka ilmeni näyttelyn jälkeen julkaistuista yleisöäänestyksen tuloksista. Tällä äänestyksellä ei ollut vaikutusta siihen, mikä teos valittiin kilpailun voittajaksi. Kilpailun palkintolautakunta valitsi kilpailun voittajaksi Aurinkokaupunki-teosehdotuksen. Palkintolautakunta totesi voittaneesta teosehdotuksesta seuraavaa:

Ehdotus on mielenkiintoinen, siinä on tulevaisuuteen luotaava näkökulma ja innovatiivinen ote. [...] teos keskittyy valoon, väreihin, heijastuksiin ja se sijoittuu eri kohteisiin; joenrantaan ja asuinalueella olevaan puistoon. Teos edustaa

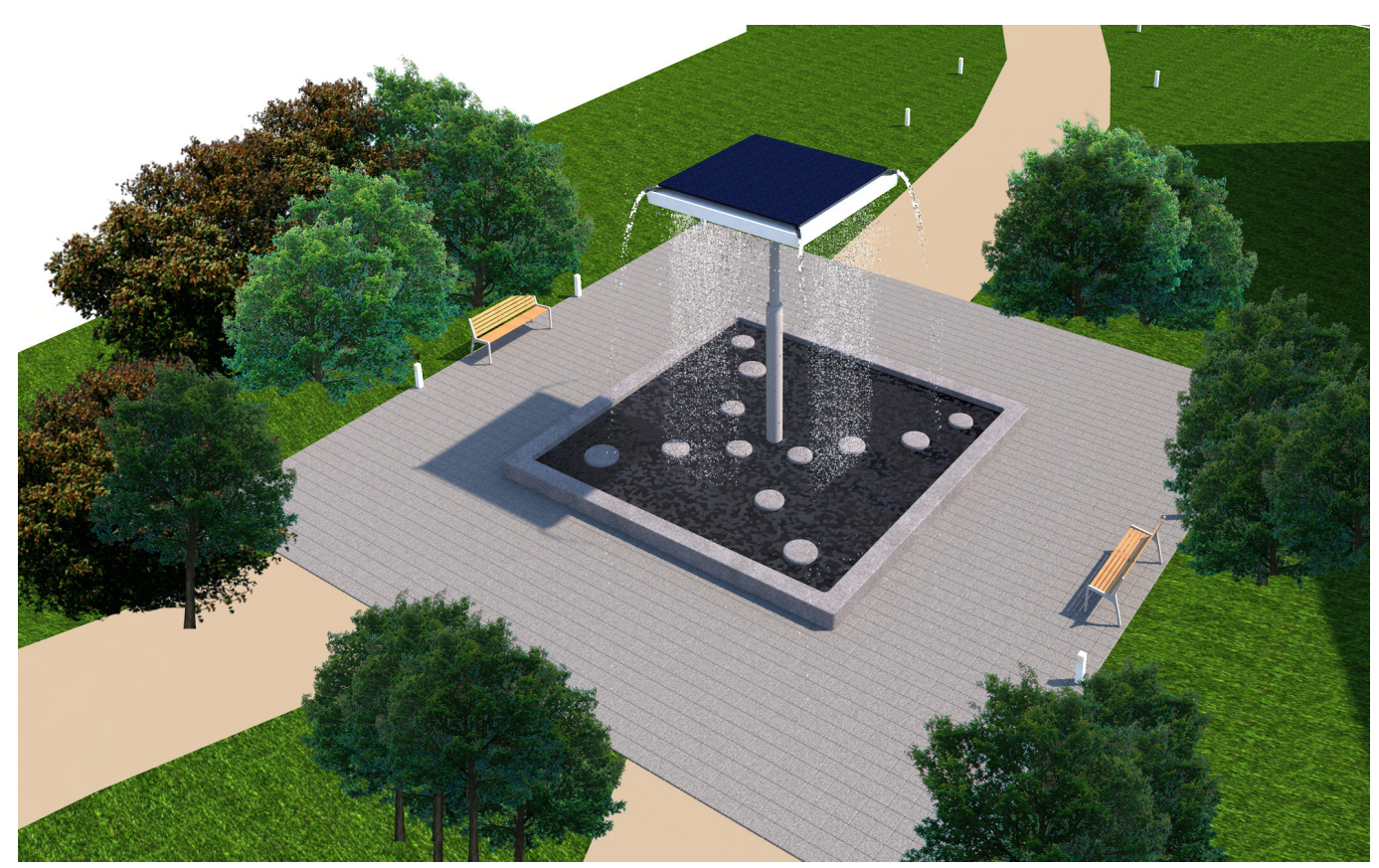

Kuva 1. Suihkulähde yläviistosta kuvattuna. Luonnoskuva: Solaria. 
uudenlaista teknistä toteutusta, johon sisältyy riskejä. Teos on teknisesti haastava, se koostuu muun muassa aurinkoenergiaan liittyvistä järjestelmistä. Se on ekologinen ja se edustaa tämän päivän, mutta myös lähitulevaisuuden teknistä kehitystä. [...] Aurinkokaupunki teos voi kantaa kestävän kehityksen lippua asuntomessualueella ja sitä kautta kannustaa asukkaita ekologiseen elämäntapaan. (Karjarannan taidesuunnittelukilpailun palkintolautakunnan pöytäkirja, 19. 11. 2015, s. 4.)

Aurinkokaupunki on kahteen puistoon ja joenrantaan sijoitettava teoskokonaisuus, joka koostuu suihkulähteestä ja penkki- sekä työskentelykatoksista. Kaikki rakennelmat on katettu aurinkopaneeleilla ja niissä on led-näytöt, joihin tulee esille taiteilija Mirja Vallinojan videoteoksia. "Videot kertovat meditatiivisella hiljaisten muutosten tyylillä auringon kaikkea maapallon elämää liikuttavasta voimasta. Kuvat ovat pääosin värjätty lämpimin värein niin, että hämärässä kaukaa katsottuna hiljaa liikkuvat kuvat, voivat näyttää lyhdyiltä, joissa palaa elävä tuli" (Solaria, 2015). Teoskokonaisuus koostuu perinteisistäja kokeilevista elementeistä.Seedus- taa asioita, joita olemme tottuneet näkemään kaupunkitilassa, mutta siihen on lisäksi sisällytetty uusia, monille vielä aika tuntemattomia toimintoja. Suihkulähde edustaa perinteistä julkista taidetta. Se on visuaaliselta ilmeeltään moderni, katosmainen rakennelma, jossa on kahluuallas. Lähde on sijoitettu asuntoalueen puistoon. Suihkulähteen yläpuolella olevan katoksen alapinta koostuu led-näytöstä, jossa on tarkoitus esittää liikkuvaa videokuvaa, katoksen yläpinnassa on aurinkopaneelit. Pohjoisessa ilmastossa suihkulähteen vuosittainen käyttöaika on erittäin lyhyt, mutta taiteilijan suunnitelman mukaan suihkulähteessä olevat videot ja valolaatat valaisevat lähiympäristön myös talvella, jolloin se toimii valotaideteoksena.

Penkkikatokset on sijoitettu jokirantaan, ja niitä tulisi olla jokaisen asuinkorttelin kohdalla. Myös niissä on aurinkopaneelit ja led-näytöt. Joelta ja vastarannalta katsoessa ne toimivat voimakkaina visuaalisina elementteinä, kutsuvina portteina, niissä olevan liikkuvan videokuvan ansiosta. Penkkikatokset yhdistävät perinteisiä ja kokeilevia asioita; ne ovat puistonpenkkejä, jotka ovat kaupunkilaisille tärkeitä levähdys- ja virkistäytymispaikkoja, mutta samalla ne edus-

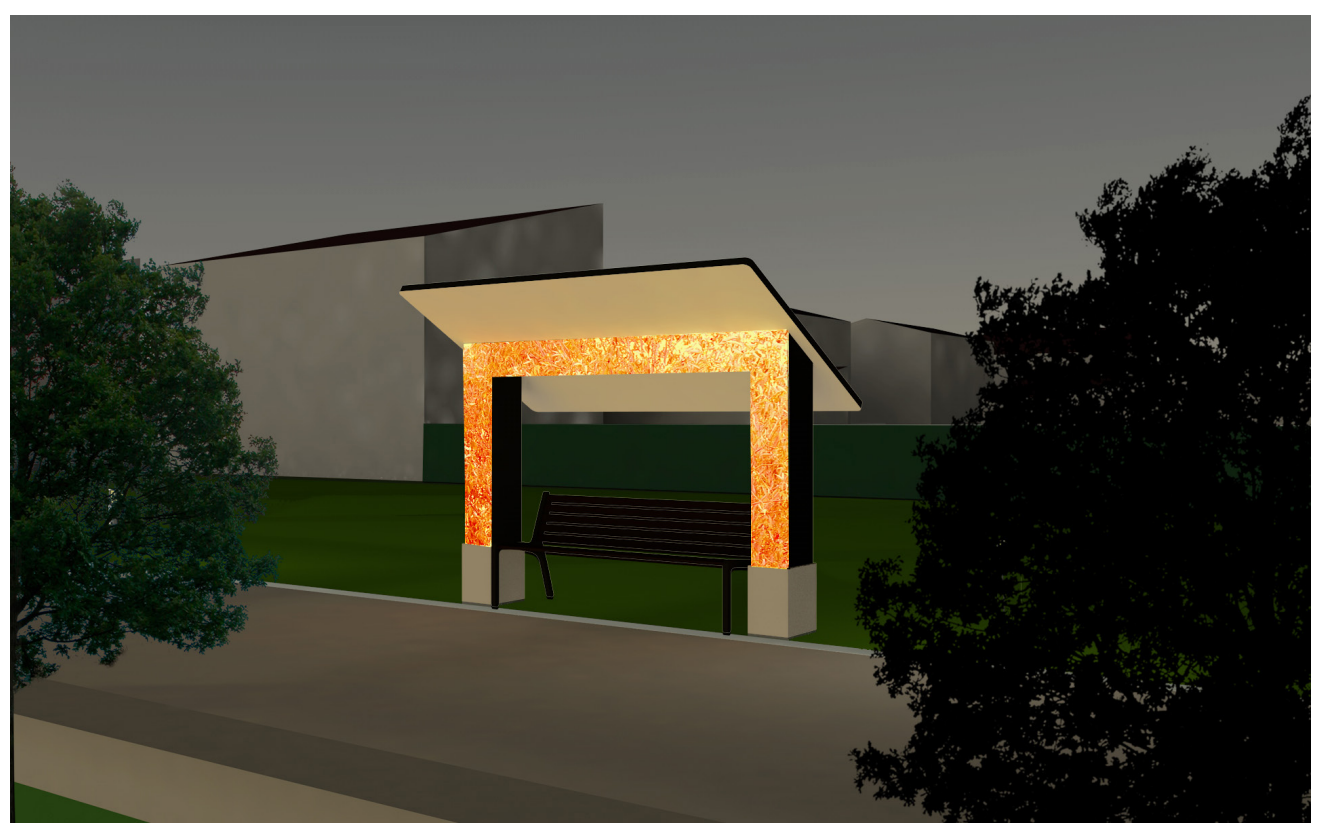

Kuva 2. Penkkikatos. Luonnoskuva: Solaria 


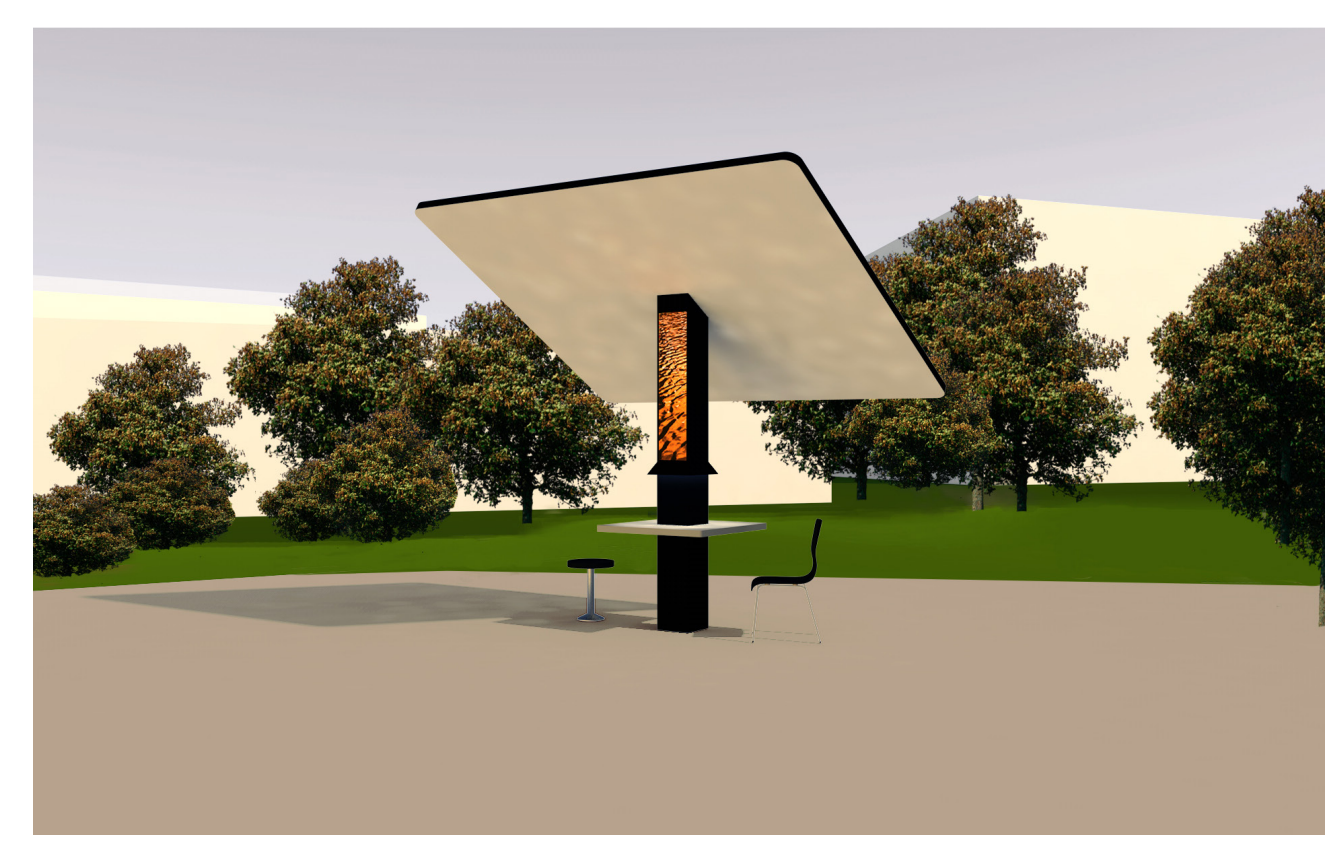

\section{Kuva 3. Työskentelykatos. Luonnoskuva: Solaria}

tavat jotakin aivan uutta ja erilaista.

Työskentelykatokset on tarkoitus sijoittaa leikkipuiston, oleskeluaukion tai kylätalon läheisyyteen. Niiden rungossa on työskentelytaso, latauspistokkeita ja led-videopalkki. Lipan alla on työvalo. Työskentelykatokset voivat toimia myös kohtaamispaikkana tai yhteisöllisinä työpisteinä.

\section{Johtopäätöksiä}

Tarkastellessani Karjarannan asuntomessualueen kaavoitusprosessia ilmeni, että asemakaavan osallisuus- ja arviointisuunnitelmalla oli ratkaiseva rooli siinä, että prosenttitaide sisällytettiin asemakaavaan. Kulttuurilautakunta oli määritetty osallisuus- ja arviointisuunnitelmassa suunnittelu- ja lähialueen osalliseksi. Lautakunta antoi lausunnon, jossa se korosti, että messualueen suunnittelun eri vaiheissa tulee huomioida prosenttiperiaate. Lausunto sisällytettiin asemakaavaan sen luonnosvaiheessa. Karjarannan asemakaavaan on ehdotusvaiheessa vielä lisätty määräys taiteen liittämisestä alueen arkkitehtuuriin ja ympäristösuunnitteluun ja maininta löytyy myös lainvoimaisesta kaavasta. Messualueen asemakaava hyväksyttiin ennen kuin taidekilpailun voittaja julkistettiin. Näin ollen kilpailun voittaneen taiteilijan kanssa ei neuvoteltu teosehdotuksesta ja sen sijoituksesta ennen kuin asemakaava hyväksyttiin.

Kilpailulla tavoiteltu suunnitteluyhteistyö toteutui ainoastaan kilpailun työryhmän ja taiteilijoiden välillä, moniammatillisena verkostotyönä. Suunnittelun toteutuminen muiden kuin kilpailun työryhmään kuuluvien suunnittelijoiden välillä ei voinut käytännössä toteutua muun muassa sen vuoksi, että osa kaupunkisuunnittelun virkamiehistä kuului kilpailun palkintolautakuntaan, jolloin he eivät saaneet olla yhteyksissä kilpailuun osallistuvien taiteilijoiden kanssa. Taidesuunnitteluun olisi pitänyt nimetä asemakaavasuunnittelija, kuten Vantaan asuntomessujen suunnittelun yhteydessä tehtiin.

Kilpailun aikana järjestettyjä seminaareja, koulutusta ja yhteisiä tapaamisia pidettiin hyvänä avauksena moniammatilliseen ja poikkihallinnolliseen yhteistyöhön sekä verkostoitumiseen. Kilpailun prosessikuvaus tuo esille, että projektissa tehtiin poikkihallinnollista verkostotyöskentelyä, koska siihen osallistui kunnan vir- 
kamiehiä eri toimialoilta sekä valtion virkamies, läänintaiteilija. Jos taiteilija määritellään yksityiseksi palvelun tuottajaksi, voidaan lisäksi puhua moniammatillisesta verkostotyöskentelystä. Läänintaiteilija Marjo Heinon rooli Karjarannan taidekilpailun suunnitteluprosessissa on ollut erittäin tärkeä myös siksi, että taidehankkeita ei automaattisesti kytketä uusien asuinalueiden suunnitteluprosesseihin. Ilman läänintaiteilijaa ja hänen vahvaa omistautumistaan tehtävälleen, kilpailu ei olisi toteutunut. Monet kilpailuun osallistuvista taiteilijoista tunsivat ennestään läänintaiteilijan, joten heidän oli helppo ottaa hänen yhteyttä ja keskustella hänen kanssaan kilpailuun liittyvistä asioista.

Jos tulevaisuudessa haluamme taiteilijoiden osallistuvan asuinalueiden suunnitteluun, pitäisi tämä huomioida taiteilijoiden koulutuksessa tarjoamalla esimerkiksi kursseja, joissa tehdään suunnitteluyhteistyötä eri alan ammattilaisten kanssa. Maankäyttö- ja rakennuslain määrittämän pätevyysvaatimuksen mukaan suunnittelijalla tulee olla korkeakoulututkinto ja riittävä työkokemus. Vaativuuskriteereitä on mahdollista soveltaa korkeakoulututkinnon suorittaneeseen taiteilijaan, jolla on riittävä tai soveltuva työkokemus. Arkkitehtien ja suunnittelijoiden koulutuksessa ja kunnallishallinnossa olisi hyvä mahdollistaa suunnitteluyhteistyö taiteilijoiden kanssa, jotta moniammatilliseen yhteistyöhön ja yhteissuunnitteluun syntyisi luonteva ote.

Suunnitteluyhteistyön alkuvaiheessa saivat kaikki muut osapuolet paitsi kuvataiteilija(t) palkkaa tehdystä työstä. Kuvataiteilijat toimivat usein ammatissaan ilman säännöllistä toimeentuloa. Suunnitteluprosessit ovat aikaa vieviä ja vaativia, joten olisi suotavaa, että niihin osallistuvat taiteilijat, muutkin kuin kilpailun voittaja, saisivat suunnittelutyöstä palkkion. Karjarannan taidekilpailussa jatkoon päässeille finalisteille maksettiin tehdystä työstä palkkio. Mikäli taiteilija toimisi suunnittelutyöryhmän jäsenenä, tulisi hänelle maksaa palkkaa tehdystä työstä aivan samoin kuin muillekin työryhmän jäsenille maksetaan.

Prosenttiperiaatteen ohjausryhmä ehdottaa loppuraportissaan, että taiteen asiantuntijapalveluita ja taidekonsultaatiotoimintaa, raken- nustietosäätiön ylläpitämää taidepankkia ja ammattimaisten taideasiantuntijoiden roolia pitäisi vahvistaa (Opetus- ja kulttuuriministeriö, 2017, s. 22). Kaupunkien ja kuntien kaavoitukseen ja kaupunkisuunnitteluun liittyvissä ehdotuksissa ei mainita lainkaan asukasosallistumista. Asukkaat tuntevat hyvin asuinalueensa, joten heitä voisi käyttää asuinalueensa kokemusasiantuntijoina. Asuinalueella asuvia taiteilijoita voisi hyödyntää oman asuinalueensa suunnitteluun ja kehittämiseen. Asuinalueiden moniammatillisissa virkamies- / aluetyöpöydissä voisi olla mukana asukasedustaja ja mahdollisesti myös alueella asuva taiteilija, joka edustaisi ammattikuntaansa. Työryhmässä olisi hyvä olla mukana edustaja kaupunkisuunnittelusta, joko kunnalliselta puolelta tai kunnalliselle puolelle töitä tekevä konsultti. Olisi tärkeää, että taiteilija ja asukas edustavat omaa yhteisöään. Ehdokasvalinnan tekisivät taiteilija-/ asukasjärjestö tai yhteisön jäsenet.

Olisi suositeltavaa, että Suomen Asuntomessut ja asuntomessujen isäntäkunnat palkkaisivat taidealan asiantuntijan koordinoimaan ja tuottamaan messuihin liittyviä taidehankkeita sekä tarvittaessa toimimaan taiteilijoiden apuna ja välittäjänä taiteilijoiden, kaupungin toimialojen, rakennuttajien ja alueen toimijoiden välillä, kuten on toimittu Arabianrannan rakentamisen yhteydessä. Suomen Asuntomessujen tulisi tehdä läheistä yhteistyötä sekä kaupunkisuunnittelun että kulttuurihallinnon kanssa, jolloin voitaisiin edistää prosenttitaiteen toteutumista rakennushankkeen varhaisessa vaiheessa.

Tutkin kyselylomaketutkimuksen avulla, mitä mieltä kaupunkilaiset ovat asiantuntijavetoisesta taidekilpailusta. Kyselyyn vastanneet edustavat pientä otantaa, eikä vastausten perusteella voi tehdä yleisiä johtopäätöksiä. Niin ikään vaikuttaa siltä, että kyselyyn vastasivat sellaiset henkilöt, jotka ovat kiinnostuneita Porin asuntomessuista. Todennäköisesti kyselyn toteutuspaikka vaikutti otantaan ja näin myös kyselyn tuloksiin. Jotta olisi tavoitettu sellaisia henkilöitä, jotka eivät käytä kirjaston palveluita olisi kysely pitänyt toteuttaa esimerkiksi ostoskeskuksessa tai kadunvarsikyselynä.

Tutkimuksessa kysyttiin, pitäisikö kau- 
punkilaisille antaa mahdollisuus osallistua julkisten taidekilpailuiden suunnitteluprosesseihin. Suurin osa vastaajista oli sitä mieltä, että kaupunkilaisilla pitäisi olla mahdollisuus osallistua taidekilpailuiden suunnitteluprosesseihin. Toisaalta ainoastaan neljä henkilöä oli osallistunut Karjarannan asuntomessualueen asemakaavan esittelytilaisuuksiin. Tämä tulos kuvastaa vastausten ja osallistumisen välillä vallitsevaa ristiriitaa. Suurin osa vastaajista ilmoittaa, että suunnitteluosallisuuteen pitäisi olla mahdollisuus, mutta ainoastaan murtoosa on osallistunut asemakaavan esittelytilaisuuteen kun sellainen on järjestetty. Tämän vastaajaryhmän osalta vaikuttaa siltä, että asemakaavan esittelytilaisuus ei riittävällä tavalla edistä asukkaiden vaikuttamismahdollisuuksia ja osallistumista suunnitteluprosessiin. Pääosa vastaajista ilmoitti haluavansa olla mukana suunnittelussa jo alkuvaiheessa esimerkiksi internetin välityksellä, edelleen sekä alku- että loppuvaiheessa mukanaolo sai paljon kannatusta.

Viime vuosina kaupunkisuunnittelussa on ryhdytty kehittämään arkkitehtuurikilpailuiden verkko-osallistumista, koska se mahdollistaa laaja-alaisen osallistumisen ja erilaisten teknisten ratkaisuiden monimuotoisen esittämisen. Samoja ratkaisuja voisi soveltaen hyödyntää julkisten taideteosten kilpailuiden yhteydessä. Kysymykseen voisi myös tulla jonkinlainen digitaalinen joukkoistamistyökalu tai alusta, jolla voitaisiin kerätä ideoita tai kommentteja jatkokehittämistä varten. Verkkokyselyiden kohdalla pitää kuitenkin huomioida saavutettavuuteen liittyvät kysymykset, jotta kaikilla väestöryhmillä on mahdollisuus osallistua niihin tai verkkokyselyiden ohella pitäisi tarjota muitakin osallistumistapoja.

Digitaalinen vuorovaikutteisuus ja osallistaminen on tullut 2010-luvulla myös osaksi asuntomessujen suunnittelua. Osuuskunta Suomen Asuntomessujen toimitusjohtajan Pasi Heiskasen mukaan internet on hyvä väline osallistavaan ja sosiaaliseen yhdessä tekemiseen sekä suunnitteluun. Hänen mielestään sitä voi myös käyttää kilpailuiden arviointiin. (Heiskanen, haastattelu, 7.10.2015.) Kyselyn vastaajat ovat sitä mieltä, että julkisen taiteen kilpailuja kannattaisi avata kaupunkilaisille, jotta heillä olisi mahdollisuus osallistua tai kommentoida taideteoksia suunnitteluvaiheessa. Suomen Asuntomessujen toimitusjohtajan Pasi Heiskasen näkökanta osallistavasta suunnittelusta korreloi Karjarannan suunnittelukilpailun aikana toteutetun kyselyn vastausten kanssa.

Kolmanneksi tavaksi osallistua suunnitteluprosessiin nousi työpajatyöskentely. Työpajatyöskentely voi toimia hyvänä vuorovaikutteisena tiedonkeruumenetelmänä, johon voi yhdistää erilaisia osallistamisen metodeja. Yhteisöllistä ideointia (co-creation) eli tässä tapauksessa kaupunkilaisten ja virkamiesten yhteistä ideointia voisi toteuttaa esimerkiksi kaupunkisuunnittelutyöpajassa. Asukkailta voisi esimerkiksi kerätä ennen kilpailun alkua ajatuksia, kokemuksia, toiveita ja/tai muistoja paikasta, jonne julkista taideteosta suunnitellaan. Työpajan tuloksia voisi hyödyntää kilpailuohjelman suunnittelussa. Taidekilpailuissa voisi asiantuntijaraadin rinnalla toimia asukasraati. Demokraattista päätöksentekoa edistävä raati olisi sellainen raati, jossa olisi sekä asiantuntija- että maallikkojäseniä.

Kyselyyn vastanneiden näkemys julkisesta taiteesta edustaa samoja ajatuksia kuin prosenttitaiteen tavoitteet ja Suomen Asuntomessujen julkisen taiteen ohjelma. Kaupunkialueelle toivottiin kokonaisvaltaista suunnittelua. Suomen Asuntomessujen linja julkisen taiteen suhteen on kokonaisvaltainen; taide on osa ympäristörakentamista ja ihmisten arkista asuinympäristöä. Nämä tavoitteet löytyvät myös prosenttitaiteen ohjelmasta. Julkisella taiteella on mahdollista vaikuttaa siihen, miten asukkaat ottavat omakseen asuinalueella olevan julkisen tilan ja minkälaiset sosiaaliset kohtaamispaikat alueelle muodostuvat. Vastaajat toivovat yhteisöllisiä teoksia. Voittajateos Aurinkokaupunki edustaa innovatiivista julkista taidetta, joka sisältää juuri niitä elementtejä, joita vastaajat toivovat asuinalueille eli luonnon elementtejä (vettä), kokonaisvaltaista suunnittelua, paikkasidonnaisuutta, toiminnallisuutta ja interaktiivisuutta. Julkiseen taideteokseen sisällytetty video- ja mediataiteen ulottuvuus on 
harvinaista Suomessa. Taiteilija Mirja Vallinoja on ehdottanut, että teoksessa olevissa näytöissä voidaan esittää festivaaliluonteisesti tai kausittain vaihtuvia, muidenkin taiteilijoiden videoteoksia. Tämän toiminnan kautta voi avautua uudenlainen näkökulma julkiseen taiteeseen, ja kaupunkilaisten toivomat ulottuvuudet, yhteisöllisyys, vaikuttaminen ja osallistuminen, toteutuvat. Mediataidetta on harvoin esillä kaupunkitilassa ja teos tarjoaa sen esittämiseen uudenlaisen konseptin. Teoksen omavarainen sähköntuotanto aurinkopaneelien avulla on uudenlainen ekologinen ulottuvuus julkisen taiteen kentällä.

Karjarannan messualue on vanhaa teollisuusaluetta, joka kaavoitettiin asuinkäyttöön. Uudella asuinalueella dialogia taideteoksen ja asukkaiden välille taideteoksen suunnitteluvaiheessa on mahdotonta luoda, mutta julkinen taideteos voidaan kuitenkin toteuttaa vuorovaikutuksessa kaupunkilaisten kanssa.

\section{Jälkikirjoitus}

Aurinkokaupunki -teos toteutui alkuperäistä ideaa huomattavasti supistetummassa muodossa. Teoksesta toteutettiin ainoastaan suihkukaivo videoteoksineen, sijoituspaikkana Kokemäenjoen ranta. Teos sai uuden nimen Aurinkolähde. Alkuperäisessä teosehdotuksessa olevat penkki ja työskentelykatos eivät toteutuneet. Asuntomessualueen projektipäällikkö Kari-Matti Haapalan mukaan taiteilijan alkuperäinen ehdotus ei ollut toteuttamiskelpoi- nen ja ehdotus olisi tullut liian kalliiksi toteuttaa. Taiteilija Mirja Vallinojan näkökulma on, että kilpailussa toivottiin koko alueen kattavaa suunnitelmaa, jonka hän oli myös toteuttanut. Vallinojan mukaan messuille on pyritty toteuttamaan teos, johon sekä tilaaja, kaupunkilaiset ja taiteilija ovat tyytyväisiä. Taiteen edistämiskeskus myönsi taidekilpailun voittaneen työn toteutukseen 25000 euroa. Teoksen toteutusta tuki lisäksi Porin kaupunki. Teokseen budjetoitiin 120000 euroa. (Satakunnan Kansa / Kulttuuri 18. 4. 2016.)

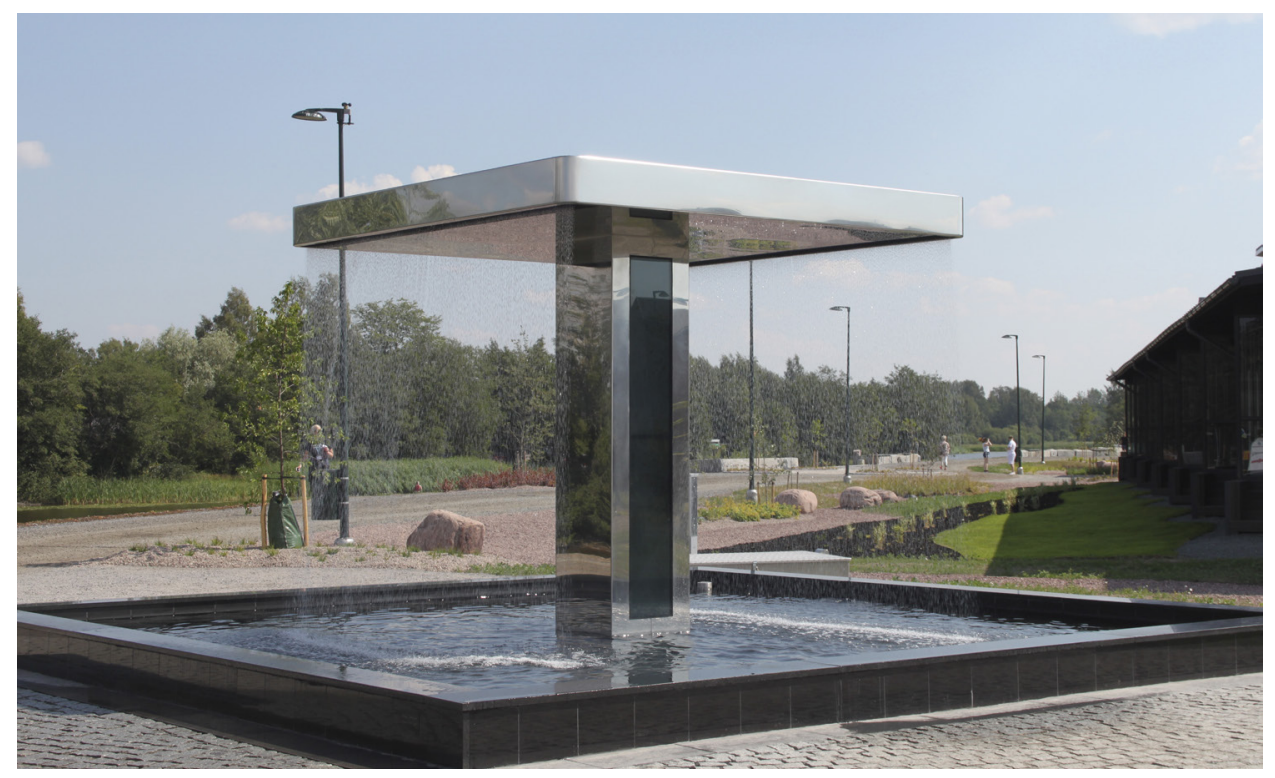

Kuva 4. Aurinkolähde (2018), Karjarannan asuntomessualue. Kuva: Pia Hovi-Assad. 


\section{Lähteet ja kirjallisuus}

\section{Haastattelut}

Heino, Mario, läänintaiteilija. Taiteen edistämiskeskus. Haastattelu 1 1. 8. 2015, haastattelija Pia Hovi-Assad. Tallenne kirjoittajan hallussa.

Heiskanen, Pasi, toimitusjohtaja. Osuuskunta Suomen Asuntomessut, Helsinki. Puhelinhaastattelu 7. 10. 2015, haastattelija Pia Hovi-Assad. Tallenne kirjoittajan hallussa.

Pesonen, Katja, suunnitteluhortonomi. Porin kaupunki / Katu- ja puistosuunnittelu. Haastattelu 29. 10. 2015, haastattelija Pia Hovi-Assad. Tallenne kirioittajan hallussa.

\section{Tutkimuskirjallisuus}

Haapanen, I. (2017). Kaupunginteatteri on nyt myös kuvataiteen näyttämö. Turun Sanomat Kulttuuri 10. 11. 2017.

Harju, P. (1988). Yhteissuunnittelu asuinalueiden kehittämisessä. Yhdyskuntasuunnittelun täydennyskoulutuskeskus. Espoo: YTK:n julkaisuja A 15.

Hautio, M. (2016). Tutkimuskohteena osallistava taidetoiminta. M. Hautio (toim.) Tavoittaako taide? Kokemuksia kunta- ja alvetaiteilijasekä lähiöhankkeista. (18-35). Humanistinen ammattikorkeakoulu, julkaisuja 25.

Hyry, J. (2016). Kansalaisten käsityksiä taiteesta osana arkiympäristöä ja julkisia tiloja. DOI: http://prosenttiperiaate.fi/wp-content/uploads/Kyselytutkimus-2016.pdf [haettu 11. 7. 2017]

Isohanni, T. (2006). Arabia Arabia Taiteellinen toiminta osana asuinympäristön suunnittelua, tapaus Arabianranta, Helsinki. Helsinki: Taideteollisen korkeakoulun julkaisu A 66.

Isoherranen, K., Rekola, L. \& Nurminen R. (2008). Enemmän yhdessä-moniammatillinen yhteistyö. Helsinki: WSOY Oppimateriaalit Oy.

Järvipetäiä, M. \& Nikkilä, A. (2012). Esipuhe. Teoksessa M. Järvipetäiä \& A. Nikkilä (toim.) Taide rakennushankkeessa. Opas tilaajalle. (910). Helsinki: Suomen Rakennusmedia Oy.

Karjaranta 21 (s.d.). Asuntomessuteemat. URL: http://www.karjaranta21.fi/teemat/ [haettu 4.4.2017]

Karjarannan taidesuunnittelukilpailun palkintolautakunnan pöytäkirja, 19. 11. 2015.

Kaukovirta, K. (2018). Prosenttiperiaatteen uudet tuulet tuovat mediataidetta ja aluesuunnittel- va. Turun Sanomat Kulttuuri 4. 3. 2018.

Kekäläinen, T. (2010a). Kuvataide rakennetussa ympäristössä. Teoksessa H. Mamia (toim.) Kuvanveisto ajassa ja tilassa. (46-53). Helsinki: Suomalaisen Kirjallisuuden Seura.

Kekäläinen, T. (2010b). Kuvataide strategisena ja alveellisena tekijänä. Teoksessa Kekäläinen T. (toim.) Prosenttitaiteen vuoksi. A Percent for Everyone: Integrating Public Art and Architecture. (33-49). Oulu: Oulun taidemuseon julkaisuja 52.

Kuoppamäki, E. \& Salmi, J. (2001). Asuntomessut 1970-2000 Ajankuvia \& suuntalinjoja. Helsinki: Suomen Asuntomessut.

Kyhä-Mantere, A. (2013). Asuntomessujen hakemista esitetään kaupunginhallitukselle. URL: https://www2.pori.fi/uutiset/2013/02/ asuntomessujenhakemistaesitetaankaupunginhallitukselle.html\#.WsH7dGenErQ [haettu 2. 4. 2018]

Laasanen, J. \& Laakso, A. (2013). Poriin tulee Euroopan ensimmäinen ruokapuisto. YLE Uutiset Kotimaa 28.1 1.2013. URL: https://yle.fi/uutiset/3-6958496 [haettu 30.11. 2017]

Loppuraportti Asuntomessut Oulussa 2005. URL: http://www.asuntomessut.fi/sites/default/ files/loppuraportti_ilman_reunuksia.pdf [haettu 11.9.2015]

Lättilä, H. (2018). Jyväskylä vei Kankaan alveella prosenttiperiaatteen askeleen pidemmälle - rakennusliikkeet kiittelevät mallia. Rakennuslehti 27. 3. 2018. URL: https://www. rakennuslehti.fi/2018/03/iyvaskyla-vei-kankaan-alueella-prosenttiperiaatteen-askeleen-pidemmalle-rakennusliikkeet-kiittelevat-mallia/ [haettu 2. 7. 2018]

Maankäyttö- ja rakennuslaki (1999/132). URL: https://www.finlex.fi/fi/laki/ajantasa/1999/19990132 [haettu 8. 12. 2017]

Maankäyttö- ja rakennusasetus (1999 / 895) URL: https://www.finlex.fi/fi/laki/ajantasa/1999/19990895\#L1 P3 [haettu 9. 7. 2018]

Mikkelin kaupunki. Palvelumuotoilu haastaa asukkaat mukaan ideoimaan URL: http://www. madmikkeli.com/lahipalveluiden-kehittamistyopaja-palvelumuotoilun-menetelmin/ [haettu 3. 1. 2018]

Miles, M. (1997). Art Space and the City. Public Art and Urban Futures. London: Routledge.

Opetus- ja kulttuuriministeriö. (2017). Esitys prosenttitaiteen edistämiseksi Ohjausryhmän raportti. Helsinki: Opetus- ja kulttuuriministeriön julkaisuja 2017:50. DOI: http:// julkaisut.valtioneuvosto.fi/bitstream/handle/10024/160373/OKM_50_2017.pdf 
Porin kaupungin kulttuurilautakunta. (KAUS /1143/2013). Hevosluodon (59.) kärki ja Karjarannan (21.) länsiosa 1. asemakaava ja asemakaavan muutos Porin asuntomessut 2018 . Kulttuurijohtajan päätösehdotus.

Porin kaupunki (2015). Karjarannan taidesuunnittelun ideakilpailun kilpailuohjelma. Porin kaupunki, Tekninen palvelukeskus ja puistotoimi 13. 1. 2015. URL: https://www2.pori.fi/material/attachments/hallintokunnat/tekninenpalvelukeskus/puistotoimi/taidesuunnittelu/ W29iyYPOx/150105_kilpailuohjelma.pdf [haettu 5. 8. 2015]

Porin kaupunkisuunnittelu. Hevosluoto, Karjaranta, Hanhiluoto 609 1632. URL: https:// www.pori.fi/kaupunkisuunnittelu/kaavat/ asemakaavat/voimassa-olevat-asemakaavat/hevosluoto-karjaranta-hanhiluoto [haettu 5. 7. 2018]

Porin kaupunkisuunnittelu. (2014a). Hevosluodon (59.) kärki ja Karjarannan (21.) länsiosa, Porin asuntomessut 2018 asemakaavan muutos, 1. asemakaava 609 1631. Dnro KAUS/103/2014 VP $\S 47 / 21.10 .2014$ URL: https://drive.google.com/drive/folders/1 fyf-IUal5SonAYD2wCDumutzpoez919v [haettu 5. 7. 2018]

Porin kaupunkisuunnittelu. (2014b). Hevosluodon (59.) kärki ja Karjarannan (21.) länsiosa, Porin asuntomessut 2018 asemakaavan muutos, 1. asemakaava 609 1632. Dnro KAUS/103/2014 VP $\S 47 / 28.10 .2014$ URL: https://drive.google.com/drive/folders/1 fyf-IUal5SonAYD2wCDumutzpoez919v [haettu 5. 7. 2018]

Prosenttiperiaate URL: www.prosenttiperiaate.fi [haettu 9. 12. 2015]

Prosenttiperiaate. Taideohjelma. URL: http:// prosenttiperiaate.fi/taideohjelma [haettu 8. 12. 2017]

Salminen, T. (2013). Asuntomessut Poriin vuonna 2018. URL: https://www2. pori.fi/uutiset/2013/05/asuntomessutporiinvuonna2018.html\#.WsH8a2enErQ [haettu 2. 4. 2018]

Sanders, B.-N. E. \& Stappers, J.P. (2008). Co-creation and the New Landscape of Design. Co-Design 4 (1), March 2008, 5-18. DOI: https://www.tandfonline.com/doi/ abs/10.1080/15710880701875068 [haettu 8. 1. 2018]

Solaria (nimimerkki). (2015). Aurinkokaupunki. URL: $\quad$ http://www2.pori.fi/material/images/hallintokunnat/tekninenpalvelukeskus/ puistotoimi/taidesunnittelu/OfG2s 1 iqf/Aurinkokaupunki[1].jpg [haettu 15.1.2018]
Suomen Asuntomessut. (s.d.). Toiminta-ajatus. URL: http://asuntomessut.fi/organisaatio/ osuuskunta/toiminta-ajatus/ [haettu 6. 8. 2015]

Suomen Asuntomessut. (s.d.) Messuhistoria. URL: http://asuntomessut.fi/organisaatio/messuhistoria/kotka-2002/ [haettu 6. 8. 2015]

Suomen Taiteilijaseura. (2014). Prosentti taiteelle. URL: http://artists.fi/ajankohtaista/ hankkeet-ja-projektit/prosentti-taiteelle/ [haettu 4. 7. 2018]

Taidemaalariliitto. (s.d.). Taide ja taiteilija kaavoituksessa. URL: http://www.painters.fi/taiteenhankintamalli/taide-ja-taiteilija-kaavoituksessa/ [haettu 4. 4. 2018]

Turpeinen, O., Miettinen, A. \& Terho, $H$. (2016). Taiteen edistämiskeskus prosenttitaiteen asialla 2014-2016. Helsinki: Taiteen edistämiskeskus. DOI: http://www. taike.fi/documents/ 1 1580/0/Prosenttiperiaatteen+kehitt\%C3\%A4misohjelman $+v \% C 3 \% A 4$ liraportti+2014-2016/46 69999c-e316-4433-a7f7-cdb8e9a9cef6 [haettu 27.7.2017]

Uimonen, L. (2010). Taidetta suunnitteluun Taidehankkeet ja taidetoiveet suomalaisessa kaupunkisuunnittelussa. Taideteollisen korkeakoulun julkaisusarja A 106. Helsinki: Aalto-yliopisto. DOI: https://shop.aalto.fi/ media/attachments/c6223/Uimonen.pdf [haettu 6. 10. 2015]

Vantaan Asuntomessut loppuraportti. (2015). DOI: http://www.asuntomessut.fi/sites/default/ files/asuntomessujen_loppuraportti_smallest. pdf [haettu 2. 8. 2018]

Vastamäki, J. (2015). Kyselytutkimus: Tutkimusasetelman ja mittareiden valinta. Teoksessa R. Valli \& J. Aaltola (toim.) Ikkunoita tutkimusmetodeihin 1 Metodin valinta ja aineistonkeruu: virikkeitä aloittelevalle tutkijalle. (121-132). Jyväskylä: PS-Kustannus.

Äijälänrannan asuntomessualueen taidekonsepti 201 1. DOI: http://www2.jkl.fi/kaavakartat/ asuntomessut/aijalanranta_taidekonsepti. pdf [haettu 6. 10.2015] 